\title{
Representation as politics: asserting a feminist ethic in ethnographic research
}

\author{
Sarah Leaney ${ }^{\mathrm{a} *}$ and Rebecca Webb ${ }^{\mathrm{b}}$ \\ ${ }^{a}$ School of Applied Social Science, University of Brighton, Brighton, UK \\ ${ }^{b}$ School of Education and Social Work, University of Sussex, Brighton, UK \\ *S.Leaney@brighton.ac.uk
}

\begin{abstract}
As ethnographers we are familiar with methodological debates problematizing ethnography's inherited and inherent connections to ideas of authenticity commonly mobilised to legitimate modes of representation. In this paper, we engage with the post-structural philosophies of Jacques Rancière and Judith Butler, to argue that methodological tools of representation are always 'political' and as such shape the limitations of what can be known. In order to trace the overlapping methodological foundations which inform our ethnographic representations, we introduce three paradigmatic constructions of ethnography. By paying attention to the ways in which our ethnographic representations mark the perceptibility of educational practices and purposes, we assert a feminist ethic through the representation of the 'livable life' as a productive methodological provocation.
\end{abstract}

Key words: post-structural ethnography; politics; representation; feminist ethic; livable lives 


\section{Introduction}

'...to situate ethnography as a ruin/rune is to foreground the limits and necessary misfirings of its project, problematizing the researcher as "the one who knows"...Attempting to be accountable to complexity, thinking the limit becomes our task and much opens up in terms of ways to proceed for those who know both too much and too little.' (Lather 2001, 482)

The troubling of claims to 'truth' permeate the practice of much ethnographic research, with critical reflections concerning ideas of authenticity and authority constituting a "crisis of representation' (Clifford and Marcus 1986; Geertz 1988; Davies 2008). Ethnography foregrounds the production of knowledge through the researcher's entanglement in all aspects of the research endeavour. It is concerned with the process and product of methodology, analysis, and text (Lather 2001). Ethnography facilitates reflections on the power of naming and knowing as fixing processes, through which moments are 'captured' and represented (Tedlock 2003). The practice of writing ethnography foregrounds analysis from the generation of the first field-note to the production of the final text (Cerwonka and Malkki 2008). Distinctively, ethnography allows for the ongoing engagement with analysis throughout the research process. It enables analytic spaces to be kept open; interpretive boundaries to be blurred; and reflexive engagements, of mind and body, to offer the possibility for alternative representations (MacLure 2013). These ways of engaging with ethnographic writing 'as a way of knowing' (Richardson 1994, 516) permit other ways of reading data; asking questions of them; reconceptualising them and finally re-presenting ${ }^{1}$ them.

\footnotetext{
${ }^{1}$ In terms of both re-presenting our data and representing them in new ways
} 
In this paper we explore the possibilities of holding open our analysis as a way of facilitating a 'feminist ethic' in our ethnographic practices within formal and informal educational settings. In so doing, we engage with a history of critical feminist writing, which foregrounds interconnections of politics, representation and ethics, that continue to resonate in ethnographic work today (Delamont 2018). We define a feminist ethic as a sensibility in our ethnographic practice that is situated, relational, affective and processual (Simons and Usher 2000; O'Connell Davidson 2008). This requires a methodology which is less about knowing more or knowing better, but rather more about 'thinking with' (Jackson and Mazzei 2012) in order to know differently (Popoviciu et al 2006). This paper involves a revisiting of the authors' $\mathrm{PhD}$ research and their ethnographic data collected within two contrasting educational sites, one a community centre (Leaney, 2018) and the other a primary school (Webb, 2017). We are concerned with ongoing struggles within our ethnographic representations of precarious lives outside dominant modes of representation; what Butler terms lives which were 'never livable' (Butler 2014, 11). It is the troubled connection between ethnographic representations and ideas of authenticity, and the defining of the perceptibility of the 'livable life' (Butler 2014), that has pushed us in our re-thinking of our data to question what it means for us to represent. How do we legitimate our claims to know? How does power circulate within the research and representation process? These questions challenge us to conceptualise educational ethnography as always a site of politics (Crossouard \& Webb 2015) that is both destabilising and productive.

\section{Structuring the paper}

We have organised the paper principally into three sections. The first, Ethnography and 
Authenticity, reprises and discusses the politics of representation and the claims of authenticity within ethnography. The second, Ethnography and the 'Distribution of the Sensible', explores the exclusionary and constructed nature of what is made real and thus possible. The third and final section, Asserting a Feminist Ethic - representation and 'the impossible', highlights the responsibility of the ethnographer to represent 'the in-between'. For us, the 'in-between' refers to the gaps forged when observations are theorised and field-notes translated into the final text. As Coles and Thompson (2016) suggest, a focus on the 'in-between' allows for new thinking, prising open the unrepresented and that which may be obscured in order to render visible the possibility of the 'livable life'. Our paper develops an argument for an ongoing commitment to asking, what remains unsaid and unseen in representations of ethnographic moments?

To contextualise our methodological approach, we briefly introduce our distinctive research projects below from which we draw the data for this paper.

\section{Sarah's research project:}

Sarah's ethnographic research was conducted over a period of eighteen months within both formal and informal educational spaces on a council estate located on the outskirts of a city in England. A central concern of Sarah's research was the exploration of classed identity formations. In this paper Sarah draws upon field-notes taken during her time in the informal educational space of the Community Centre. Here she took on the role of 'helper' during an after-school club for primary school children. The participants featured in this paper are youth workers, volunteer parents and children who all live on the council estate. 


\section{Rebecca's research project:}

Rebecca's ethnographic research was conducted over the course of ten months in one large state primary school in a small town in England. Her research interrogated a discourse of children's rights and how it was performed in everyday encounters within the school. In this paper, Rebecca draws on field-notes and personal reflections taken from different moments within the research journey, including an exchange with her $\mathrm{PhD}$ supervisor, a teacher within the school and a young pupil.

\section{Locating our argument}

The paper is located within a post-structural logic which challenges the assumptions of authenticity and objectivity in research, through mapping how 'truths' are constituted (Talburt 2004; Cairns 2013). This mapping of course encompasses ethnography itself as a site of 'truth' production, where representations reify complex lives (Britzman 1995). Thus, ethnographic representations are inherently political, in their power to define and delineate identity categorisations. Through the connection of Rancière and Butler, who both offer a definition of politics as disruption, we explore the potential of conceptualising representation as a site of politics.

We take an Rancièrian ontological view of politics as that which antagonises what is assumed through the assertion of difference: 'it makes visible what had no business being seen, and 
makes heard a discourse where once there was only place for noise' (Rancière 1999, 30). Politics is a mode of operating that disturbs the seemingly obvious order of things. Rancière calls this order of things the 'distribution of the sensible' (Rancière 2004, 12), a conceptualisation of the commonly perceptible which delineates something shared that, nonetheless, involves practices of exclusion:

'an order of bodies that defines the allocation of ways of doing, ways of being, and ways of saying, and sees that those bodies are assigned by name to a particular place and task; it is an order of the visible and the sayable' (Rancière 1999, 29)

The notion of politics as disruption articulates the possibility of making visible what is excluded from 'the sensible'. Rancière calls this, 'the impossible' (Rancière 1992, 63). 'The impossible' can be thought of methodologically, as the 'in-between', highlighting moments of analysis which might slip between different ways of understanding education: its practices and purposes. 'The impossible' therefore acts as a 'mode of expression' which undoes the division of an ordering of 'the sensible' (Rancière 2003, 30) enabling us as ethnographers to speak of moments which disrupt the way things are taken to be within formal and informal educational settings.

We suggest that Butler's conceptualisation of the 'livable life' (2014) may be utilised as a complimentary methodological tool of interrupting 'the sensible', as constituted within ethnographic representations of education. Through a re-animation of our ethnographic fieldnotes, we pursue a feminist ethic in our ethnographic practice. We aim to assert this ethic as a methodological provocation, which may promote paying attention to ways in which our representations are formative of the 'distribution of the sensible', thus marking the perceptibility of the 'livable life'. 


\section{Section One: Ethnography and authenticity}

In this section we trace the overlapping methodological foundations which inform our ethnographic representations through the construction of three paradigms. We recognise that each paradigmatic tradition is marked by the problematisation of ideas of authenticity (Clifford 1990). Nevertheless, each is formative of the distribution of 'the sensible' through the demarcation of what may constitute an authentic 'livable life'. The first captures some ideas taken from 'traditional' ethnography, which position the research relationship as one of reciprocal lacks (Cohen 2000). The second identifies aspects of 'new ethnographies' (Rosaldo 1989; St. Pierre 1997; Visweswaran 1994) which trouble authenticity through textual engagements with ideas of uncertainty. The third considers a turn to feminist post-structural ethnography (Stacey 1988; Hey 1997; Skeggs 2001) which questions the legitimation of knowledge through ideas of ethnographic representation. We suggest that these categorisations are not mutually exclusive. Rather, they each constitute the production of ethnography as an act, a 'scene for a dramatization of social practices' (Rancière 2006, 9). Indeed, we recognize the ways in which we both draw upon amalgams of all three paradigms as we construct our own logics of enquiry within our research. The following sections include examples from our ethnographies that reflect assumptions from each paradigm, informing our critical reflection on what these perspectives both enable and occlude.

\section{Traditional ethnography: reciprocal lacks}


The history of the ethnographic contract between researcher and researched is one deeply rooted in assumptions about representation (Denzin and Lincoln 2011, 48-58). Constituted in colonial ideas of voyeurism and ventriloquism, both researcher and researched have traditionally been seen through ideas of making the strange familiar' ${ }^{2}$, an 'imaginary exchange of reciprocal lacks that masks the real asymmetries of power and status' (Cohen 2000, 13). The ethnographer is assumed to lack the authenticity of the participant and the participant to lack the authoritative voice of the ethnographer. Thus, the ethnographic exchange is entangled within the supposition of fixed subject positions. On the one hand, are those with an authentic position; and on the other, are those with a voice to claim knowledge and power (Mannay 2010). The ethnographic researcher interprets and translates authenticity into forms of representation to be voiced within discourses of knowing the 'Other' within the academy (Said 1978).

This traditional construction of the researched-researcher power dynamic endures. In the following field-note, Sarah reflects on an early meeting with a research participant in the informal educational setting of the Community Centre.

The first time I met Sharon we talked about my hometown. She told me what she knew of it, that she had heard that it was where many travellers had settled. She had visited the council estate I was brought up on. She joked that it was really old fashioned, that there were kids playing with conkers. Her kids [the children who attend the Community Centre] didn't know what to make of it.

\footnotetext{
${ }^{2}$ Ethnographers of their indigenous cultures will also engage with practices of 'making the familiar strange' (see Sikes, 2003)
} 
The exchange is marked by claims of authentic subject positions in which Sarah assumed to legitimate her claim to be somewhat 'inside' the research context. At the same time, the participant Sharon, who is a resident of the council estate and works as a youth worker, refuses to be known within the construction that is proposed by the researcher. In this way, Sharon also claims some power to know.

For Sarah, what she had perceived to be a shared history of both living on a council estate, became a point of separation, through the distinctions maintained by her research participant. Sharon drew upon dominant discourses to locate Sarah's experience as 'authentic', which she could laugh at and know as different and fixed. Within a traditional ethnographic construction, there is assumed to be an inherent power in Sarah's production of knowledge through this fieldnote. Nevertheless, the relationship between the researcher and the researched is complex. The field-note illustrates that it is not simply that the researcher retains all the power within the research relationship. Rather, the defining of the Other as 'authentic' is always an ongoing process of power production where difference is in play.

\section{New ethnography: voice and reflexivity}

In the 'new' ethnographies which emerged from feminist alternative claims to know in the 1960s and 1970s, there is a destabilisation of the ontological foundations of ethnographic representation (Behar 1996; Van Maanen 1995). This move away from the explicit ventriloquism of the traditional ethnographer, instead privileges the idea of the authority of 'voice'. Lather characterises this move as marked by 'partial and fluid epistemological and 
cultural assumptions' $(2001,201)$ which give rise to fragmented and reflexive modes of ethnographic writing. This practice of representation is designed to go beyond mere appropriation. Through a troubling of an idea of 'speaking for' research participants, new ethnographies seek to make visible the intricate asymmetries of power located within traditional ethnographies. These practices produce texts in which polyvocality and multiple perspectives are championed through some re-defining of the academic text.

However, both traditional and new methodological forms of representation continue to centre on claims of authenticity. Drawing upon Gates' argument that authenticity plays a 'troublesome' role in claims of 'realness' (Gates 1991, 3), Lather calls attention to authenticity as an aspect of 'contemporary regimes of disciplinary truth-telling' (Lather 2001, 483). In this way, both traditional ethnography constructing representations through analysis, and new ethnography through the displaying of 'raw' data, methodologically evokes authenticity as a mechanism to capture that which they seek to know. Such capturing can be conceived of as the championing of ethnographic representations as mere objects of 'Show and Tell' (Webb 2014), where data is presented in its raw form as though it can speak for itself.

Although Rebecca's research, conducted within the formal educational setting of the primary school, did not explicitly fall within this tradition of privileging participant voice, it is clear looking back at an early field-note, that description is used as a tool of authentic representation. Here Rebecca describes how Children's Rights are communicated through displays around the school:

Rights - they appear everywhere, both concretely, as well as, somehow, floating in the 
ether - not so much on their own - but coupled with 'respect', dressed up as 'responsibility': they're on the walls in UNICEF brightly coloured poster form; as 'home-made' school charters on the walls of corridors, classrooms, hallways, outside in the playground, on newsletters home, reminders of what can be expected ('you have the right to be heard', and 'you have the right to work' and 'you have the responsibility to listen'... 'and to let others get on with their work')... They feel invested in, by many, and in such a range of spaces within the school. They are a garment, not so much worn lightly, as with a mark of distinction... they are asking to be recognised and valorised. This is Top Hill Primary saying, 'Hey, this is what we're about... sit up and take notice'.

Rebecca reads this now as early ethnographer anxiety in which she was keen to assert a researcher identity of 'she who knows'. In her presentation of the context through 'thick description' (Geertz 1973), Rebecca assumes knowledge production to be a process where participant's lives are laid bare requiring no further interpretation for the reader. Lather describes this as an act of appropriation of 'the lives of others into consumption of a too-easy, too-familiar eating of the other' $(2001,206)$. Through Rebecca's claim to know, the school becomes fixed and reified as authentic.

\section{Feminist ethnography: power and representation}

Through acts of de-familiarisation that challenge disciplinary assumptions of authenticity, Lather complicates the position that authenticity refers to 'singular, transparent, static identity categories assumed to give the writer a particular view' (Lather 2001, 483). Hence, feminist 
ethnography does not offer a competing ontological frame, rather it looks 'at the historical, philosophical and cultural construction of frames' (Lather 2001, 479), both in terms of the object of research and the research methodology itself. As Skeggs argues, it is a politics of 'how we should do research' (Skeggs 2001, 4).

In the note below, Rebecca's PhD supervisor responds to a draft chapter, where Rebecca had sought to engage with a textual 'experiment'. Rebecca is faced by the limits of the deconstructive frame within which she was trying to work. Her weary supervisor comments:

Make a note about the aesthetic and the blinking tyrannies of the way your supervisor is used to apprehending ideas. We want things going forward in your next piece of writing - these people are difficult to please [she said referring to herself]. Now we have shone a light on it [the chapter] we have found that it doesn't do the work that it needs to do yet.

(Rebecca's recording of supervisory session November, 2012)

Many of Rebecca's supervisory sessions focused upon this representational tension that required her to manage her authorial role and the responsibility that comes with this. Reflections on the practices of writing help us think about the role of methodological techniques in representation and the ability of the ethnographer to communicate the experience of 'being there'. There is always a tension between the construction of the text and the comprehension of the reader. The responsibility of the author is to navigate and work 'inbetween' these tensions produced by 'regimes of disciplinary truth telling' (Lather 2001, 483). For Rebecca this was experienced as always a compromise between the difficulties of undoing 
authorial voice and the pressures to adhere to disciplinary conventions.

Feminist research asks, "who has the power to do, write, authorize and distribute research in the name of feminist ethnography?' (Skeggs 2001, 3). It is concerned with power: who holds it, where and how. Skeggs calls for an analysis of the process of ethnography. It is the ongoing posing of questions of process and power that constitute post-structural feminist theorisations that inform practices of ethnography, "not only as a method but [as] a form of questioning and analysis' (Skeggs 2001, 5).

Such an analysis of the processes of ethnography may help to make visible paradigmatic assumptions underpinning disciplinary modes of representation. In Sarah's field-note below, she considers the role of the ethnographer's recording device. The notebook symbolically legitimises her researcher performance ${ }^{3}$. As a prop it supports the identity claims she makes through 'being there'. It acts as a mark of distinction: it is a physical barrier between her and the people she seeks to know, an act of distancing which makes visible some of the ontological and epistemological assumptions of her research at this time (Hammersley and Atkinson 2007).

I wonder why I chose something imitating the traveller's log, the classic anthropologists' choice. I think there's a symbolic authority connected with the book. It's tactile, the leather look case is masculine and its apparent age indicated through its almost curling sides and spattered faux leather gives a sense of authenticity to my role. But if this is my recognition, an academic fantasy role play, who will recognise

\footnotetext{
${ }^{3}$ The ethnographer's notebook has been variously problematised and re-appropriated as a participatory tool (see Russell, 2011)
} 
my performance? Am I trying to speak to participants through this manipulation of artefact or to other academics who will recognise its symbolic meaning?

(Sarah's field-notes, June 2013)

The ethnographic practice enacted here implies that one may remain free of the binds of social interaction within the educational space, where the ethnographer exists on the peripheries of a moment, looking in. The act of note taking assumes a social dexterity, that the researcher may 'be there' as both participant and observer (Clifford 1990). The notebook endows the researcher with the privilege of distance. It symbolises a disconnection, a social disinvestment in the moment and relieves the researcher of the responsibility of maintaining social interactions. It reveals a particular ontological assumption, that although the social may be constructed in its enactment by agents, it is something that can be observed, founded upon ideas of continuity and stability, unaffected by the distanced researcher. The recording of these moments through descriptive note-taking reveals an epistemological assumption of ethnographic research, that the social may be captured by the distanced researcher in text.

As the two field-notes above illustrate, feminist ethnography requires an attention to the power relations that are immanent within all social processes. Ethnography as a research methodology is very far from providing answers to questions of representation. Nonetheless, in this section, we have shown that in contesting ideas of certainty, its methodologies can provide thinking tools with which to explore the production of representation as text. We have introduced our ethnographic practice through an explication of three ethnographic paradigms: traditional, new and feminist. Through a consideration of the parameters each paradigm assumes, we argue that ethnographic representation is formative of the distribution of 'the sensible'. It is to this we 
turn in the following section, where we offer an engagement with ethnographic representation as an act of politics (Rancière 1999).

\section{Section two: Ethnography and the 'distribution of the sensible'}

'politics is an act of impurity, a process that resists purification...Politics makes visible that which a social order wishes to render invisible, and it does so in such a way that it does not just "add" to what is already given. Instead, it undermines the purity of the given.' (Chambers 2011, 305)

In keeping with the characterisation of politics in the quote above, we suggest that all educational ethnographic representation is politics. It is a moment, an act, or a representation that challenges the ontological premise of a given frame at any one time (Rancière 2004b). This could be, for example, valorising speech which is usually dismissed, or occurrences which are seemingly trivial. The significance of this is a challenge to dominant representations, where everyday lived experiences may offer alternative ways of knowing. Politics, therefore, is a disruption, rendering visible the possible limits of established knowledge.

In this section, we connect feminist ethnography as a politics of how we should do research, to a Rancièrian logic of politics as momentary rupture. We suggest that Skeggs' methodological reflexivity concerning the processes of knowledge production, can be brought together with Rancière's politics as impurity, in order to help us expand the possibilities of a feminist ethic for research. By drawing attention to the role of ethnography in undermining the "purity of the given' (Chambers 2011, 305) rather than simply adding to what is known, we suggest that this conceptualisation of politics provides an alternative representational possibility. 
By re-directing the ethnographic gaze onto the situated practice of educational ethnography, Rebecca's field-note below makes visible the assumptions underscoring the formation of research relationships within the classroom. The fieldnote captures an interaction with George, a teacher with whom she has been working closely:

Ahh, what does George think I've been doing? I know that I rarely sit and take notes in the classroom - I've long abandoned that: it's so uncomfortable - takes me back to being the 'School Inspector' - but I do write (frantically) in other places round the school away from an all too public gaze to capture my observations and thoughtsGeorge knows that, and we talk and discuss these notes... But what does this mean for my ethical legitimacy - all that stuff which presumes that everyone is clear about my role as a researcher...? Once again, I feel that I'm just pretending to do this ethnography properly but not.

(Rebecca’s field-note, January 2012)

The field-note reflects Rebecca's yearning for a clear sense of researcher authenticity. The moment she captures occurred once she had been part of the school for several months. She felt compromised by a suggestion from George, that they must both make time for her to start her research within the classroom 'properly'. This brief reflexive note captures some of the possibilities of Skeggs' notions of feminist ethnography $(1994,2001)$. What Rebecca perceived to be fixed and stable positions of researcher and participant were contested in George's imagining of what it means to do research. Read as Rancièrian politics, the methodological act of representing moments of unease can disrupt aspects of the ethnographic form, producing 
new articulations of disciplinary 'truth-telling'.

Nevertheless, attempts to represent the complexity of ethnography are never unproblematic: the edification of such moments are necessarily caught within disciplinary practices of representation. Hence, politics as an act of impurity is recaptured within what can be known. In this way, ethnographic representations such as that above can only rupture fleetingly. Thus, 'politics has no 'proper' object...all its objects are blended with the objects of [the sensible]' (Rancière 2003,4). Understood as politics, ethnographic representations are constitutive of 'ways of doing, ways of being, and ways of saying' (Rancière 1999). Similarly, Skeggs' ideas of feminist ethnographic practice enable an analysis characterised by discomforting questioning that can make visible the representational power of ethnography. By also thinking with Rancière's conceptualisation of politics, we suggest that this further allows for a critical engagement with academic representations, through an exploration of the ways representations (re)constitute that which they critique.

In the field-note that follows, we further explore these ideas of politics and rupture through a moment of disruption within Sarah's ongoing negotiations of access to the community centre. Sarah is part of an interaction in which she is positioned by Holly, a resident of the council estate, as different and outside the assembled group of volunteers at the community centre:

In the break between the clubs, I struggled to keep up with the banter. Holly had cooked a pizza for us all to share. She got it out the oven, slipping it on to a tea towel, she carried it over to the kitchen work top in the middle of room and slapped it down. After slicing it with a rolling cutter she stepped back as the group began to help themselves. 
Holly looked at me, and with a smile said 'I'll get you a plate Sarah, you don't look like the sort to eat without one'. As she walked over to the cupboard I asked 'Would you get me a knife and fork too?' For a moment the room went silent, it wasn't until I began to laugh that they realised I was joking.

(Sarah's field-notes, December 2013)

The research participant, Holly, identifies as part of the group within the community centre. She lays claim to Sarah's difference through her own identification with the wider community. Though there are perceived differences between them, Sarah's engagements with 'banter' mean that she is able to form some connections with the group of volunteers. Through drawing attention to Sarah's deployment of humour and irony within the moment and captured within the note, this becomes a moment of politics which 'makes visible that which a social order wishes to render invisible' (Chambers 2011, 305). We can construct this representation as not so much a 'looking in' or a holding still of an authentic way of being, but rather as a way of paying attention to the practices of the everyday that can be made visible through the act of the research encounter. Thus, politics is not simply contained within specific moments of disruption in the field but may also be extended into the ethnographic text.

In this section, we have explored what Skeggs' call for a re-directing of the ethnographic gaze onto the situated practice of ethnography, may produce in our analyses. We have suggested that both the moment of the ethnographic encounter and the production of the ethnographic text, become sites of politics. In the following section, we further develop our connection between Skeggs' feminist ethnography and Rancière and Butler's theorisations of the politics of visibility, in order to argue for a feminist ethic in our ethnographic representations. 


\section{Section three: Asserting a feminist ethic - representation and 'the impossible'}

The conceptualisation of politics as rupture is 'always on the verge of disappearing' (Rancière 2004b, 7). As we have described in the previous section, moments of politics are formative of the distribution of 'the sensible' where disruption is reincorporated through an 'identification with social groups or imaginary bodies' (Rancière 2004b, 7). As Butler asserts, there is always a tension within post-structural representations which 'invariably fail to complete' (Butler 1999, 182).

A commonality in the work of both Butler and Rancière is their concern with the ontological assumption of representation as 'an act, a way of configuring and dividing the domain of the sensible' (Pelletier 2012, 280). Both draw theoretical attention to that which is rendered invisible through claims of representational visibility. Thus, 'the impossible' becomes that which is always located outside or beyond the distribution of 'the sensible'. Crucially, however, 'the impossible' also interrupts 'the sensible', 'challenging the accepted perceptible givens' (Rancière 2004b, 7).

Below we utilise the concept of 'the impossible' not to assert an alternative logic, rather instead, to explore what an interest in ontological disruptions can produce that is deserving of ethnographic attention. We develop our connection between Skeggs' feminist ethnography and Rancière and Butler's theorisations of visibility, in order to argue for a feminist ethic in our 
ethnographic representations. We suggest this feminist ethic should centre attention on moments that we have found hard to capture fully because they remain on/beyond a periphery. In so doing, we explore our responsibility as ethnographers to represent what becomes positioned as 'in-between' through a re-engagement with our respective field-notes.

In the following field-note and discussion, Sarah explores the play of some young children as part of an after-school youth club within the community centre.

I was in the 'living' style room with a few of the younger kids. They are 4-5 years oldKabir, Sam, and Carly. Kabir was making them laugh by pulling a face where he looked up through his eyebrows and in a mock Middle Eastern accent he was saying 'What are you doing?' and 'I shoot you'/ 'I shoot you in the head'. The kids were rolling about with laughter. Sam said, 'He's talking in his own language', but I said, 'He's saying, “What are you doing?" in a different voice'. I asked Kabir where he got the voice from and he said he made it up. One of the kids said Kabir could speak another language, but when I asked Kabir he didn't answer.

(Sarah's field-note, November 2013)

This field-note represents a moment of disjuncture in two ways: first, in Sarah's own discomfort as children play with ideas of race, difference, and violence; and, second, as a moment of rupture and negotiation, a confounding of social space. The community centre of Sarah's research was formed predominantly of White British, working-class families. Within this context, Kabir, as one of the few Black British children, was highly visible. Paradoxically, this difference was central to constructions of the 'community' within the centre. Kabir became both a symbol of the community centre's inclusivity, whilst also re-affirming the normative 
sensibility of the community as White and working-class. Kabir's visibility was articulated through his positioning as resident 'character' in the centre. His energy, confidence and humour, coupled with his size and age (he is only four but very small) creates a spectacle focussed on his performance. He is often the centre of attention and appears to feed off this energy, gradually becoming louder and louder, and his speech faster and faster, whilst also spitting out jokes and profanities.

The field-note above references one such performance of Kabir's caricature of a 'foreign villain'. His performances are physical; he uses his small body and the speed of his movements for comedic effect, distorting his face and body in jerky, broken movements. His 'foreign villain' skit centres on a stereotypical 'Middle-Eastern' accent and an aggressive questioning of his audience. When performing to the crowd, he jumps around the room, moving towards each spectator, leaning in close to their face, pointing, and declaring 'What are you doing?' Seemingly enraged by their laughter, in character, Kabir flies at his audience, crying 'I shoot you; I shoot you in the head'. His audience is thrilled, and continues with their laughter, further encouraging Kabir's performance.

In many ways, Kabir was in a position of power within these interactions. He instigated the joke; he created the caricature of the 'foreign villain', drawing upon multiple discourses of difference and danger. In the moment of the joke, he is both idolised by the other children and ushered into their group, where he re-affirms his position as a 'character' of the after-school club. Yet, for his audience, Kabir's performance is connected to markers of difference. Though he maintains his coveted position of 'character', this is necessarily a position of 'Other'. Thus, 
his jokes and caricatures are attached to him as another example of his difference: the accent seems to become conflated with his racialized position.

This ethnographic interaction is a moment of rupture where the contingency of 'the sensible' is made visible. Kabir's play may be read as making sensible the imitative quality of race (Butler, 1993), where the stability of racialized identities are disrupted and transformed in the act of a performance. Nevertheless, held within the tension of 'the sensible' and 'the impossible', Kabir's performance is understood by his audience within the perceptibility of 'imaginary bodies' (Rancière 2004b, 7). Though the act of the 'foreign villain' makes sensible the shared identity of the group, aspects of the 'foreign villain' become entangled with Kabir's difference: he is Black and Sam and Carly are White. The 'foreign' accent of Kabir's performance is connected to his raced identification (Hall 1996) and becomes another marker of difference. Sam cannot see Kabir's 'foreign villain' as an act. It is not a joke. Rather the performance is understood as an expression of Kabir's identity: 'He can speak another language', says Sam.

In Rebecca's field-note below we further explore the possibility of holding still a moment of rupture within the production of the ethnographic text. In the following field-note, Rebecca observes an encounter within the school assembly hall during a rehearsal for a play. Tensions are running high between members of the teaching staff and the children who are excited. Underlying the ethos of the production are unspoken assumptions of progressive principles of inclusion, with the lead being a 10-year-old boy defined by the school as having Special Educational Needs. However, there is a disconnect between the performance of inclusivity and the pressures of the orchestration of the school play. 
James is to be the narrator. He's the prince. It will be his job to ride his wooden hobbyhorse on and off the stage. James has a wonderful cloak and crown and he also has Special Needs. He's doing a great job. He's remembered his lines and he's coming on and going off the stage at the right moments and his teacher is really, really pleased with him. 'Thumbs Up' to James. And then his crown falls down over his face and it's funny. It's really funny. And everyone laughs and some children point. James lifts his crown and looks at everyone laughing and pointing at him, and he laughs at himself and at everyone laughing at him: he's 'Mister Funny Man' now. James laughs more, and slaps his sides and looks around. It's such a 'Good Show'. James is a funny boy.

(Rebecca's field-notes, March 2012)

So James is 'the lead' in this year's show. This is supposed to be the safe space where he can feel confident enough to laugh at himself and his whole self is not risked. Yet, on his little wooden hobbyhorse, he must move along a tightrope. He is required, at one and the same time, to both 'stick out' and 'blend in'. This is not a comfortable or straightforward position for anyone. Ahmed suggests that 'comfort' is about a 'sinking feeling': bodies that 'can sink into spaces that extend their shape' (Ahmed 2012, 40). James may 'sink in' to this rehearsal for a time but this cannot last. He has been invited to be different. The difference that he's been asked to display is that of 'lead' but what we all see, of course, is that James is just 'different'. But this should not feel so difficult to execute, surely, for the very point of the liberal discourse of rights is to give 'voice' to those who can all too easily be excluded, 'acknowledging “difference" as the norm, rather than the aberration' (Devine 2002, 304). 
But it is difficult. And for those teachers - all of whom must embody the relaxed ease of the power sharing of 'redistributive leadership' required of them by the rights discourse - look to Rebecca as though they feel anything but 'comfort'. They wear their bodies taut with tension. How aware is James that it is his body that causes the discomfort that cannot be named and must not be 'recognised'? Does he know that it is on his shoulders that falls the job of 'work[ing] hard to make others comfortable' (Ahmed 2012, 41)? After all, his position of 'lead stranger' in this enterprise seems to mean that the very act of his inclusion hails it as a 'form of exclusion' (Ahmed 2012, 43). Therefore, within inclusive education, it is 'the labelling of difference [that] always carries with it the risk of stigma and reification despite [the] democratising ideologies [of inclusion]' (Rapp and Ginsburg 2011, 169).

In this analysis, Rebecca is grappling with the logic of rights, which makes sensible 'inclusion' as "a process by which those who are already "included" reach out to those who are not and bring them in to the existing order' (Pelletier 2009, 267). Therefore, the supposition of 'inclusion' becomes 'impossible' within the distribution of 'the sensible': to be 'included' requires the dissolution of difference, yet it is difference which is the object of inclusion. Nevertheless, attention to such moments makes visible the tensions between the 'sensible' and the 'impossible' as a claim of representational visibility. It is this focus on the everyday negotiations of the 'sensible' and the 'impossible' that characterises our methodological engagement with the 'livable life'.

Despite the paradoxical positions of Kabir and James within the ethnographic representations above, we argue this everyday slippage between exclusion and inclusion within education is central to the experience of lives often reified within dominant representations. We characterise 
the assertion of the 'livable life' as a necessary disruption which may go some way towards 'challenging [the] accepted perceptible givens' (Rancière 2004b, 7), not only within the moment of enactment but also as an ethic of representation through ethnographic text.

Consequently, as ethnographers, we consider our role to be that of challenging the symbolic division between the 'order of speech and that of bodies' (Rancière 2004b, 5). In so doing, we recognise speech as 'symbolic determination', rather than as physical capacity, and actively question the distribution of 'the sensible' though representations of the peripheral. Through our analyses above, we have characterised 'impossible' moments as those marked by ontological 'in-between-ness'. For James and Kabir, being caught between different and often opposing perceptions of reality, is formative of their everyday lived experience, whether they are included or excluded. Therefore, an analysis of the 'in-between' requires us to pay attention to everyday negotiations of multiple identifications. We suggest that moments 'in-between' visibility and invisibility / recognition and misrecognition are central to the imaginary of a feminist ethic as they are constitutive of what Butler terms the 'livable life' (Butler 2014, 8). She describes this herself as a 'relax[ation] of the coercive hold of norms... which is not the same as transcending all norms' (Butler 2014, 8). Within the practice of a feminist ethic that we are seeking, we translate the 'livable life' to be made possible through an enactment of representation. Through the re-animation of our ethnographic data, we have sought to recognise everyday negotiations that are formative of 'the sensible': a methodological engagement with moments otherwise invisible within dominant modes of perceptibility.

\section{Conclusion}


In this paper, we have explored the possibilities of asserting a feminist ethic in educational ethnography. Assuming a post-structural paradigm, we have sought to share moments of our ethnographic data collected within formal and informal educational settings, in order to illuminate some ways of knowing differently. In the re-visiting of our field-notes, we have aimed to disrupt the reduction of our ethnographic data as nothing other than a capturing of how things are. We have problematized ethnography's inherited and inherent connections to ideas of authenticity, drawing attention to the ways in which our own research has been shaped, nonetheless, by different histories of ethnographic practice. We assert a conceptualisation of educational ethnographic representation as always a site of politics, as it antagonises what can be assumed. We suggest that ethnographic representation forms one site of politics, making 'visible what had no business being seen' (Rancière 1999, 32). We have framed ideas of the 'sensible' and the 'impossible' as analytic tools that have enabled both a critique and a disruption of 'perceptible givens' (Rancière 2004b, 7) within the practice and purpose of education. By paying attention to ethnographic data that we have found difficult to capture, we have explored the quality of 'in-between-ness' through the theorisation of the co-constitution of the 'sensible' and the 'impossible'.

This paper has materialised a provocation that has taken us some way towards the possibility of representing ethnographically lives which were 'never livable' (Butler 2014, 11) within our educational contexts. By bringing together Rancière's conceptualisation of the 'impossible' with Butler's commitment to representations of the 'livable life' (Butler 2014, 11) we have sought to ask ourselves, what remains unsaid and unseen in our ethnographic representations. 


\section{Bibliography}

Ahmed, S. 2012. On Being Included: Racism and Diversity in Institutional Life, Durham and London: Duke University Press

Back, L. 2007. The art of listening. London: Bloomsbury Publishing

Behar, R. 1996. The Vulnerable Observer: Anthropology That Breaks Your Heart. Boston: Beacon

Britzman, D.P. 1995. 'The Question of Belief: Writing Poststructural Ethnography'. Qualitative Studies in Education, 8(3) pp. 229-238.

Butler, J. 1993. Bodies that Matter: On the Discursive Limits of Sex. New York; London: Routledge

Butler, J. 1999. Gender Trouble: Feminism and the Subversion of Identity. Routledge: New York and London

Butler, J. 2014. Rethinking Vulnerability and Resistance. Madrid

Cairns, K. 2013. 'Ethnographic locations: the geographies of feminist post-structural ethnography', Ethnography and Education, 8(3), pp. 323-337, DOI: 10.1080/17457823.2013.792675

Cerwonka, A. \& Malkki, L.H. 2008. Improvising Theory: Process and Temporality in Ethnographic Fieldwork. Chicago: University of Chicago Press

Chambers, S.A. 2011. 'Jacques Rancière and the Problem of Pure Politics', European Journal of Political Theory, 10(3), pp. 303-326

Cohen, P. 2000. From The Other Side of the Tracks: The Ethnographic Imagination as Really Useful Knowledge. University of East London

Coles, R. \& Thomson, P. 2016. 'Beyond records and representations: inbetween writing in educational ethnography', Ethnography and Education, 11(3), pp. 253-266, DOI: $10.1080 / 17457823.2015 .1085324$

Clifford, J. \& Marcus, G.E. 1986. Writing Culture: The Poetics and Politics of Ethnography. Berkeley, California; London: University of California Press

Clifford, J. 1990. 'Notes on (Field) Notes'. In Sanjek, R. (Ed.). Fieldnotes: The Makings of Anthropology (pp. 47-70), Ithaca; London: Cornell University Press.

Crossouard, B \& Webb, R. 2015. 'Learners, politics and education'. In: Scott, D and Hargreaves, E (eds.) The Sage handbook of learning. SAGE Publications Ltd, London. ISBN 9781446287569 
Davies, C.A. 2008. Reflexive Ethnography: A Guide to Researching Selves and Others. Abingdon: Routledge

Delamont, S. 2018. 'Field notes and the ethnographic self'. In: Jeffery, B \& Russell, L (Ed.). Ethnographic Writing. Ethnography and Education Publishing.

Denzin, N.K. and Lincoln, Y.S. (Ed.). 2011. The Sage handbook of qualitative research. London: Sage

Devine, D. 2002. 'Children's Citizenship and the Structuring of Adult-Child Relations in the Primary School', Childhood, 9, (3), 303-320

Gates Jr, H.L. 1991. “'Authenticity’ or the Lesson of Little Tree'. New York Times Book Review, 24(1), pp. 26-30.

Geertz, C. 1973. The Interpretation of Cultures. New York: Basic Books.

Geertz, C. 1988. Works and Lives: The anthropologist as author. California: Stanford University Press.

Hall, S. 1996. 'Who Needs Identity' in Hall, S. and Du Gay, P. eds., (1996). Questions of Cultural Identity. London: SAGE Publications.

Hammersley, M. \& Atkinson, P. 2007. Ethnography: Principles in Practice. London: Routledge

Hey, V. 1997. The Company She Keeps: an ethnography of girls' friendships, Buckingham: Open University Press

Jackson, A. Y. \& Mazzei, L. A. 2012. Thinking with Theory in Qualitative Research, viewing data across multiple perspectives. Abingdon: Routledge

Lather, P. 2001. 'Postmodernism, Post-Structuralism and Post (Critical) Ethnography: Of Ruins, Aporias and Angels'. In Atkinson, P., Coffey, A., Delamont, S., Lofland, J. and Lofland, L. (Ed.). Handbook of ethnography. London: Sage

Laws, C. 2011. Poststructuralism at Work with Marginalised Children, Bentham Books.

Leaney, S. 2018. 'Habitus as foregrounded history: theorising affect in the social formation of embodied practice', British Journal of Sociology of Education, DOI: $10.1080 / 01425692.2018 .1525681$

MacLure, M. 2013. 'The Wonder of Data', Cultural Studies $\leftrightarrow$ Critical Methodologies, 13(4), pp. 228-232

Mannay, D. 2010. 'Making the familiar strange: can visual research methods render the familiar setting more perceptible?', Qualitative Research, 10 (1), pp. 91-111 
O'Connell Davidson, J. 2008. 'If no means no, does yes mean yes? Consenting to research intimacies'. History of the Human Sciences, 21(4), pp.49-67

Pelletier, C. 2009. 'Rancière and the poetics of the social sciences', International Journal of Research \& Method in Education, 32, (3), pp.267-284

Pelletier, C. 2012. 'No time or place for universal teaching: The Ignorant Schoolmaster and contemporary work on pedagogy'. In J. Deranty, A. Ross (Eds.), Jacques Rancière and the Contemporary Scene. London: Continuum

Popoviciu, L. Haywood, C. \& Mac an Ghaill, M. 2006. 'The promise of poststructuralist methodology: ethnographic representation of education and masculinity', Ethnography and Education, 1(3), pp. 393-412, DOI: $10.1080 / 17457820600836871$

Rapp, R. \& Ginsburg, F. 2001. 'Enabling disability: Rewriting kinship, reimagining citizenship', Public Culture, 13, (3), pp. 533-56

Rancière, J. 1992. 'Politics, Identification, and Subjectivization', The Identity in Question, 61, pp. 58-64

Rancière, J. 1999. Disagreement: Politics and Philosophy. Minneapolis: University of Minnesota Press

Rancière, J. 2003. 'The Thinking of Dissensus: Politics and Aesthetics', presented at Fidelity to the Disagreement, Goldsmiths College, University of London, London

Rancière, J. 2004. 'Who Is the Subject of the Rights of Man?', The South Atlantic Quarterly, 103, 2/3, pp. 297-310

Rancière, J. 2004b. 'Introducing Disagreement', Journal of the Theoretical Humanities, 9(3), pp. 3-8

Rancière, J. 2006. 'The Ethical Turn of Aesthetics and Politics', Critical Horizons, 7(1), pp. $1-20$

Richardson, L. 1994. 'Writing: A Method of Inquiry'. In N. Denzin and Y. Lincoln Handbook of Qualitative Research (2nd Ed.), Thousand Oaks: Sage

Rosaldo, R. 1989. Culture and truth: The Remaking of social analysis. Boston: Beacon

Russell, L. 2011. Understanding Pupil Resistance - Integrating Gender, Ethnicity and Class: an Educational Ethnography, Ethnography and Education Publishing

Said, E. 1978. Orientalism: Western conceptions of the Orient. USA: Pantheon Books.

Sikes, P. 2003. 'Making the Familiar Strange: A New Look at Inequality in Education', British Journal of Sociology of Education, 24, (2), 243-8 
Simons, H. \& Usher, R. (Eds.). 2000. Situated ethics in educational research. London and New York: Routledge Falmer

Skeggs, B. 1994. 'Situating the production of feminist ethnography'. In M. Maynard, J. and Purvis, J. (Ed.). Researching women's lives from a feminist perspective. Abingdon: Taylor and Francis

Skeggs, B. 2001 'Feminist Ethnography'. In Atkinson, P., Coffey, A., Delamont, S., Lofland, J. and Lofland, L. (Ed.). Handbook of ethnography. London: Sage

St. Pierre, B. 1997. 'Circling the Text: Nomadic Writing Practices', Qualitative Inquiry 10(3): pp.403-17

Stacey, J. 1988. 'Can there be a feminist ethnography?' In Women's Studies International Forum, 11 (1), pp. 21-27

Tedlock, B. 2003. 'Ethnography and Ethnographic Representation'. In N. Denzin and Y.S. Lincoln (Ed.). Strategies of Qualitative Inquiry (pp. 165-213), Thousand Oaks: Sage

Van Maanen, J. 1995. 'An End to Innocence: The Ethnography of Representation', J. Van Maanen (Ed.). Representation in Ethnography (pp. 1-35), Thousand Oaks: Sage

Visweswaran, K. 1994. Fictions of Feminist Ethnography. Minneapolis: University of Minnesota Press

Webb, R. 2014. 'Being there (NFQLR and practice traditions) and thinking beyond... what is data?' In L. Hadfield, E. McGeeney, F. Shirani (Eds.). New frontiers in qualitative longitudinal research: perspectives of doctoral and early career researchers. National Centre for Research Methods, pp. 51-64

Webb, R. 2017 ' "Being yourself': everyday ways of doing and being gender in a 'Rights Respecting' primary school'. Gender and Education. DOI: 10.1080/ 09540253.2017.1309010 